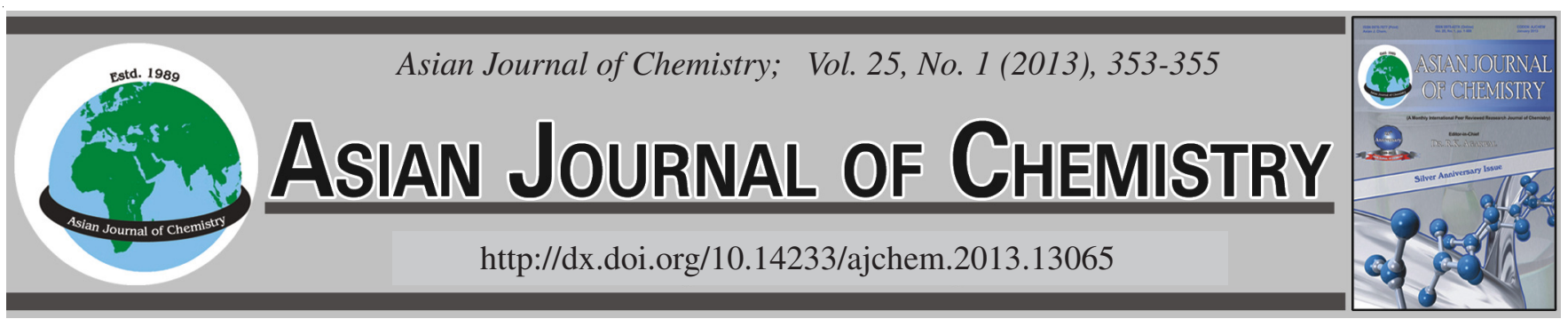

\title{
Simultaneous Determination of Chromium(VI) and Manganese(VII) by Differential Kinetic Rate Spectrophotometry of Direct Yellow Brown D3G
}

\author{
DONG ZHANG
}

School of Environmental and Chemical Engineering, Shenyang Ligong University, Shenyang 110159, P.R. China

Corresponding author: Fax: +86 24 24680345; Tel: +86 24 24680345; E-mail: sylgdxdong@ sina.com

Key Words: Direct yellow brown D3G, Fading spectrophotometry, Differential kinetic rate, Cr(VI), Mn(VII), Wastewater.

ᄂ - - - - - - - - - - - - - - - - - - - - - - - - - -

\section{INTRODUCTION}

At present, in environmental monitoring, the determination of $\mathrm{Cr}$ (VI) and $\mathrm{Mn}$ (VII) usually uses spectrophotometry, atomic absorption spectrophotometry and ICP, etc. ${ }^{1-4}$. Spectrophotometry can only determine chromium and manganese respectively. Their operations are complicated. Moreover, atomic absorption spectrophotometry and ICP needs expensive instrument. Fading spectrophotometry has been used in the respective determination of $\mathrm{Cr}(\mathrm{VI})$ and $\mathrm{Mn}(\mathrm{VII})$ for its simple operation and low $\operatorname{cost}^{5-7}$. Combination of simple fading spectrophotometry and differential reaction rate kinetic method could realize simultaneous determination of multi-components ${ }^{8-10}$. Reference cost used bordeauxred $\mathrm{R}$ or amaranth as indicator and realized simultaneous determination of $\mathrm{Cr}(\mathrm{VI})$ and $\mathrm{Mn}(\mathrm{VII})$ in steel and wastewater. However, bordeauxred $\mathrm{R}$ and amaranth were high price. But using direct yellow brown D3G, a low price textile dyes, has not been studied. In this study, based on the different reaction rate of $\mathrm{Cr}(\mathrm{VI})$ and $\mathrm{Mn}(\mathrm{VII})$ with direct yellow brown D3G, a new method for simultaneous determination of $\mathrm{Cr}(\mathrm{VI})$ and $\mathrm{Mn}(\mathrm{VII})$ was developed using the proportion equation method. This method was used to synchronously determine $\mathrm{Cr}(\mathrm{VI})$ and $\mathrm{Mn}(\mathrm{VII})$ in industrial wastewater.

\section{EXPERIMENTAL}

723 Spectrophotometer (Shanghai Precision Science Instrument Co. Ltd.); CS501 super temperature thermostat
(Shanghai Experiment Instrument Company); Standard $\mathrm{Mn}$ (VII) stock solution: $0.1 \mathrm{~g}$ of potassium permanganate was dissolved in proper amount of water and then filtered with glass sand funnel (G3). The filtrate was decanted into $1 \mathrm{~L}$ volumetric flask, diluted to scale and calibrated with sodium oxalate. It should be diluted to standard $10 \mathrm{mg} / \mathrm{L}$ working solution. $100 \mathrm{mg} / \mathrm{L}$ standard $\mathrm{Cr}(\mathrm{VI})$ stock solution: $0.2829 \mathrm{~g}$ of potassium dichromate (reference reagent) was weighed and dried at $105^{\circ} \mathrm{C}$ for $1 \mathrm{~h}$. The sample was dissolved in water, decanted into $1 \mathrm{~L}$ volumetric flask and diluted to scale; it should be diluted to standard $10 \mathrm{mg} / \mathrm{L}$ working solution. Direct yellow brown D3G (a textile dyes, come from a textile factory) solution: $1 \mathrm{mmoL} / \mathrm{L}$. All the reagents were analytically pure except otherwise specified and the water was distilled water.

Experimental principal: In sulfuric acid medium, both $\mathrm{Cr}(\mathrm{VI})$ and Mn(VII) could fade direct yellow brown D3G and the fading rate was different. The absorbance $\mathrm{A}_{0}$, of nonoxidative system at $t_{1}$ and the absorbance $\mathrm{At}_{1}$ after oxidized by $\mathrm{Cr}(\mathrm{VI})$ and/or $\mathrm{Mn}(\mathrm{VII})$ at $\mathrm{t}_{1}$ were measured. According to the additivity of absorbance ${ }^{10}$, the difference $\Delta \mathrm{At}_{1}$ was:

$$
\begin{gathered}
\Delta \mathrm{A}_{\mathrm{t} 1}=\mathrm{A}_{0}-\mathrm{A}_{\mathrm{t} 1}=\Delta \mathrm{A}_{\mathrm{t} 1(\mathrm{Mn})}+\Delta \mathrm{A}_{\mathrm{t} 1(\mathrm{Cr})}=\mathrm{K}_{\mathrm{t} 1(\mathrm{Mn}) \cdot \rho \mathrm{Mn}}+ \\
\mathrm{K}_{\mathrm{t} 1(\mathrm{Cr}) \cdot \rho \mathrm{Cr}}+\alpha_{\mathrm{t} 1(\mathrm{Mn})}+\alpha_{\mathrm{t} 1(\mathrm{Cr})}
\end{gathered}
$$

Similarly, at $\mathrm{t}_{2}$ the difference $\Delta \mathrm{A}_{\mathrm{t} 2}\left(\mathrm{t}_{2}>\mathrm{t}_{1}\right)$ could be also obtained:

$$
\begin{gathered}
\Delta \mathrm{A}_{\mathrm{t} 2}=\mathrm{A}_{0}-\mathrm{A}_{\mathrm{t} 2}=\Delta \mathrm{A}_{\mathrm{t} 2(\mathrm{Mn})}+\Delta \mathrm{A}_{\mathrm{t} 2(\mathrm{Cr})}=\mathrm{K}_{\mathrm{t} 2(\mathrm{Mn}) \cdot \rho \mathrm{Mn}}+ \\
\mathrm{K}_{\mathrm{t} 2(\mathrm{Cr}) \cdot \rho \mathrm{Cr}}+\alpha_{\mathrm{t} 2(\mathrm{Mn})}+\alpha_{\mathrm{t} 2(\mathrm{Cr})}
\end{gathered}
$$


Based on the standard curve of $\mathrm{Cr}(\mathrm{VI})$ and $\mathrm{Mn}(\mathrm{VII})$ at $\mathrm{t}_{1}$ and $t_{2}$, the proportionality coefficients $\mathrm{K}_{\mathrm{t} 1(\mathrm{Mn})}, \mathrm{K}_{\mathrm{t} 1(\mathrm{Cr})}, \mathrm{K}_{\mathrm{t} 2(\mathrm{Mn})}$ and $\mathrm{K}_{\mathrm{t} 2(\mathrm{Cr})}$ and constants $\alpha_{\mathrm{t} 1(\mathrm{Mn})}, \alpha_{\mathrm{t} 1(\mathrm{Cr})}, \alpha_{\mathrm{t} 2(\mathrm{Mn})}$ and $\alpha_{\mathrm{t} 2(\mathrm{Cr})}$ could be obtained.

The mass concentration of $\mathrm{Cr}(\mathrm{VI})$ and $\mathrm{Mn}(\mathrm{VII})\left(\rho_{\mathrm{Mn}}\right.$ and $\rho_{\mathrm{Cr}}$, in $\mathrm{mg} / \mathrm{L}$ ) could be then obtained.

$3 \mathrm{~mL}$ of direct yellow brown $\mathrm{D} 3 \mathrm{G}$ solution, $0.5 \mathrm{~mL}$ of sulfuric acid $(1+1)$ was added into two colourimetric cylinders in order and then diluted to about $15 \mathrm{~mL}$ with water. Standard $\mathrm{Cr}(\mathrm{VI})$ and/or Mn(VII) solution (oxidative system) was added into one colourimetric cylinder and the other colourimetric cylinder was added nothing (non-oxidative system). The solutions were diluted to $25 \mathrm{~mL}$ with water, shaken up and placed into a thermostatic water bath at $90{ }^{\circ} \mathrm{C}$, determined the absorbance at $1 \mathrm{~min}$ and $15 \mathrm{~min}$ (terminated the reaction with running water), the absorbance difference $\left(\Delta \mathrm{A}_{\mathrm{t} 1}\right.$ and $\left.\Delta \mathrm{A}_{\mathrm{t} 2}\right)$ of oxidative system and non-oxidative system were measured at $480 \mathrm{~nm}$ with $10 \mathrm{~mm}$ colourimetric cuvette, taking water as reference, respectively.

\section{RESULTS AND DISCUSSION}

Absorption spectra: The absorption spectra curves of each solution were shown in Fig. 1 after heating for $15 \mathrm{~min}$ at $90{ }^{\circ} \mathrm{C}$ in water bath. It could be seen that in acid, direct yellow brown D3G itself did not fade, while existence of $\mathrm{Cr}(\mathrm{VI})$ and $\mathrm{Mn}(\mathrm{VII})$ could make it fade. Moreover, there was no obvious synergistic effect between them. All curves had maximal absorption peak and $\Delta \mathrm{A}$ reached maximum at $480 \mathrm{~nm}$. Therefore, $480 \mathrm{~nm}$ was selected as measuring wavelength in this study.

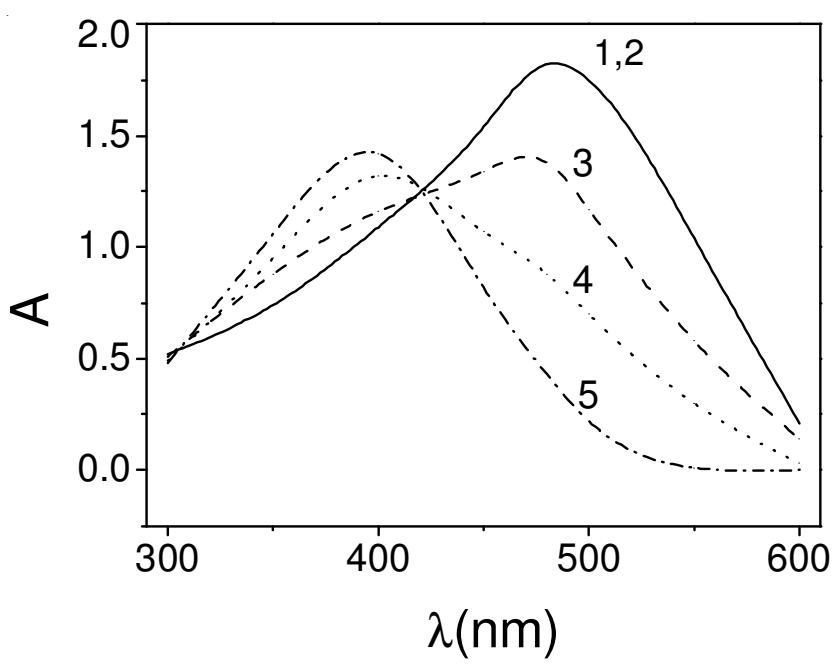

Fig. 1. Absorption spectra; (1) Direct yellow brown D3G; (2) $1+\mathrm{H}_{2} \mathrm{SO}_{4}$; (3) $2+1 \mu \mathrm{g} / \mathrm{mL} \mathrm{Mn}(\mathrm{VII})$; (4) $2+2 \mu \mathrm{g} / \mathrm{mL} \mathrm{Cr}(\mathrm{VI})$; (5). $2+1 \mu \mathrm{g} / \mathrm{mL}$ $\mathrm{Mn}(\mathrm{VII})+2 \mu \mathrm{g} / \mathrm{mL} \mathrm{Cr}(\mathrm{VI})$

Acid and its dosage: The effect of $\mathrm{H}_{2} \mathrm{SO}_{4}, \mathrm{HCl}, \mathrm{HNO}_{3}$ and $\mathrm{H}_{3} \mathrm{PO}_{4}$ and their dosage on the oxidation reaction was investigated. The results showed that whether for $\mathrm{Cr}(\mathrm{VI})$ and $\mathrm{Mn}(\mathrm{VII}), \Delta \mathrm{A}$ had maximum in $\mathrm{H}_{2} \mathrm{SO}_{4}$, when the dosage was $1 \mathrm{~mL}$. Therefore, $1 \mathrm{~mL}$ of $9 \mathrm{moL} / \mathrm{L} \mathrm{H}_{2} \mathrm{SO}_{4}$, was used in this study.

Optimal experimental conditions: The effect of reaction time at different temperatures and different dosage of direct yellow brown $\mathrm{D} 3 \mathrm{G}$ on $\triangle \mathrm{A}$ was investigated. The results showed that whether for $\mathrm{Cr}(\mathrm{VI})$ and $\mathrm{Mn}(\mathrm{VII})$, the sensitivity increased with the increase of direct yellow brown D3G dosage and reaction temperature. When the dosage of $1 \mathrm{mmoL} / \mathrm{L}$ direct yellow brown $\mathrm{D} 3 \mathrm{G}$ was $3 \mathrm{~mL}$, the reaction sensitivity reached maximum in water bath at $90{ }^{\circ} \mathrm{C}$. Higher dosage and temperature resulted in lower sensitivity. The reaction of $\mathrm{Mn}$ (VII) was complete in water bath at $90^{\circ} \mathrm{C}$ in $0.5 \mathrm{~min}$ and the reaction of $\mathrm{Cr}(\mathrm{VI})$ in $15 \mathrm{~min}$. $\mathrm{Cr}(\mathrm{VI})$ did not react with direct yellow brown $\mathrm{D} 3 \mathrm{G}$ at room temperature. Therefore, the oxidation reaction of $\mathrm{Cr}(\mathrm{VI})$ could be terminated by flowing water. The dosage of direct yellow brown D3G in this study was $3 \mathrm{~mL}$ and the reaction time in water bath at $90{ }^{\circ} \mathrm{C}$ was $1 \mathrm{~min}$ and 15 min for $\mathrm{Cr}(\mathrm{VI})$ and $\mathrm{Mn}(\mathrm{VII})$, respectively.

Working curve, detection limit and precision: The results showed that, Beer's law was obeyed in $0-11 \mu \mathrm{g} / \mathrm{mL}$ and $0-9.8 \mu \mathrm{g} / \mathrm{mL}$ for $\mathrm{Cr}(\mathrm{VI})$ and $\mathrm{Mn}$ (VII). The linear regression equations were:

$$
\begin{gathered}
\Delta \mathrm{A}_{\mathrm{t} 1(\mathrm{Cr})}=0.085 \rho_{\mathrm{Cr}}+0.029(\mathrm{R}=0.9989) \\
\Delta \mathrm{A}_{\mathrm{t}(\mathrm{Cr})}=0.157 \rho_{\mathrm{Cr}}-0.004(\mathrm{R}=0.9967)
\end{gathered}
$$

$\Delta \mathrm{A}_{\mathrm{t} 1(\mathrm{Mn})}=\Delta \mathrm{A}_{\mathrm{t} 2(\mathrm{Mn})}=0.194 \cdot \rho_{\mathrm{Mn}}+0.113(\mathrm{R}=0.999)$

Based on the above equations, the proportion equation group was obtained:

$$
\begin{aligned}
\Delta \mathrm{A}_{\mathrm{tl}(\mathrm{Cr}, \mathrm{Mn})} & =0.085 \rho_{\mathrm{Cr}}+0.194 \rho_{\mathrm{Mn}}+0.142 \\
\Delta \mathrm{A}_{\mathrm{t} 2(\mathrm{Cr}, \mathrm{Mn})} & =0.157 \rho_{\mathrm{Cr}}+0.194 \rho_{\mathrm{Mn}}+0.109
\end{aligned}
$$

The detection limits $(3 \sigma / \mathrm{k})$ of $\mathrm{Cr}(\mathrm{VI})$ and $\mathrm{Mn}(\mathrm{VII})$ were $0.81 \mu \mathrm{g} / \mathrm{mL}$ and $0.11 \mu \mathrm{g} / \mathrm{mL}$, respectively. 11 determinations for $2 \mu \mathrm{g} / \mathrm{mL} \mathrm{Cr}(\mathrm{VI})$ were conducted and the RSD tor $1 \mathrm{~min}$ and $15 \mathrm{~min}$ were $3.11 \%$ and $1.01 \%$, respectively. For 11 determinations of $1 \mu \mathrm{g} / \mathrm{mL} \mathrm{Mn}(\mathrm{VII})$, the RSD in $1 \mathrm{~min}$ and 15 min were $1.87 \%$ and $1.23 \%$, respectively.

Additivity test: After mixing the standard solution of $\mathrm{Cr}(\mathrm{VI})$ and $\mathrm{Mn}(\mathrm{VII})$ at different ratios, they were determined according to the experimental method. The contents of $\mathrm{Cr}(\mathrm{VI})$ and $\mathrm{Mn}(\mathrm{VII})$ were obtained by proportion equation. The recovery was calculated and the results were listed in Table-l. It could be seen from Table-1 that, in this linear range, the additive property of $\mathrm{Cr}(\mathrm{VI})$ and $\mathrm{Mn}(\mathrm{VII})$ was good.

\begin{tabular}{cc|cc|cc}
\multicolumn{6}{c}{ TABLE-1 } \\
\multicolumn{7}{c|}{ ADDITIVELY TEST OF Cr(VI) AND Mn(VII) } \\
\hline \multicolumn{2}{c|}{ Added $(\mu \mathrm{g})$} & \multicolumn{2}{c}{ Found $(\mu \mathrm{g})$} & \multicolumn{2}{c}{ Recovery $(\%)$} \\
\hline $\mathrm{Mn}(\mathrm{VII})$ & $\mathrm{Cr}(\mathrm{VI})$ & $\mathrm{Mn}(\mathrm{VII})$ & $\mathrm{Cr}(\mathrm{VI})$ & $\mathrm{Mn}(\mathrm{VII})$ & $\mathrm{Cr}(\mathrm{VI})$ \\
\hline 20 & 20 & 21.08 & 19.35 & 105.4 & 96.8 \\
50 & 20 & 52.31 & 18.96 & 104.6 & 94.8 \\
100 & 20 & 98.98 & 21.14 & 99.0 & 105.7 \\
20 & 50 & 20.10 & 51.25 & 100.5 & 102.5 \\
50 & 50 & 49.33 & 52.31 & 98.7 & 104.6 \\
100 & 50 & 101.52 & 48.01 & 101.5 & 96.0 \\
20 & 100 & 21.88 & 97.26 & 109.4 & 97.3 \\
50 & 100 & 48.92 & 104.58 & 97.8 & 104.6 \\
100 & 100 & 99.35 & 103.42 & 99.4 & 103.4 \\
20 & 120 & 20.66 & 124.50 & 103.3 & 103.8 \\
50 & 120 & 48.11 & 119.40 & 96.2 & 99.5 \\
100 & 120 & 95.44 & 121.80 & 95.4 & 101.5 \\
\hline
\end{tabular}

Effect of concurrent ions: In $25 \mathrm{~mL}$ of solution, $50 \mu \mathrm{g}$ of $\mathrm{Cr}(\mathrm{VI})$ and $25 \mu \mathrm{g}$ of $\mathrm{Mn}(\mathrm{VII})$ were determined according to experimental method. When the relative error was $\leq \pm 5 \%$, the allowable amounts of concurrent ions were (in $\mathrm{mg}$ ): $\mathrm{K}^{+}$, 
$\mathrm{Na}^{+}, \mathrm{Cl}^{-}, \mathrm{NO}_{3}{ }^{-}, \mathrm{PO}_{4}{ }^{3-}, \mathrm{CO}_{3}{ }^{2-}, \mathrm{NH}_{4}^{+}(50)$; hydrosulfate, EDTA, urea, $\mathrm{Mg}^{2+}(10) ; \mathrm{W}(\mathrm{VI}), \mathrm{Ca}^{2+}, \mathrm{Ni}^{2+}, \mathrm{F}^{-}(3) ; \mathrm{Zn}^{2+}, \mathrm{Co}^{2+}(5) ; \mathrm{Cr}(\mathrm{III})$, $\mathrm{A}^{3+}(1) ; \mathrm{I}^{-}$, tartrate, citrate $(0.5) ; \mathrm{Ti}(\mathrm{IV}), \mathrm{V}^{5+}, \mathrm{Pb}^{2+}, \mathrm{NO}_{2}^{-}(0.2)$; $\mathrm{Cu}^{2+}, \mathrm{Ag}^{+}, \mathrm{Fe}^{2+}, \mathrm{Fe}^{3+}(0.1)$. Therefore, most of the common ions did not interfere with the determination.

Sample analysis: $200 \mathrm{~mL}$ of wastewater sample was put into a beaker. Added 5-10 mL of $\mathrm{HNO}_{3}$, the solution was further heated to about $10 \mathrm{~mL}$. After slightly cooling, 1-2 mL of perchloric acid was added. The solution was heated dark until white smoke appeared. If the colour of solution appeared, $\mathrm{HNO}_{3}$ should be added. The solution was heated until there was no white smoke any more. After cooling, the solid was dissolved with $0.2 \% \mathrm{HNO}_{3}(\mathrm{v} / \mathrm{v})$. If some precipitation was present, the solution should be filtered. After the filtrate was cooled to room temperature, it was diluted to $10 \mathrm{~mL}$ for determination (Table-2).

TABLE-2

ANALYTICAL RESULTS OF WASTE WATER SAMPLES $\mathrm{n}=6, \mathrm{mg} / \mathrm{L}$

\begin{tabular}{lcccccc}
\hline \multirow{2}{*}{ Samples } & \multicolumn{2}{c}{ Found } & \multicolumn{2}{c}{ RSD $(\%)$} & \multicolumn{2}{c}{ Found by FAAS } \\
\cline { 2 - 7 } & $\mathrm{Cr}$ & $\mathrm{Mn}$ & $\mathrm{Cr}$ & $\mathrm{Mn}$ & $\mathrm{Cr}$ & $\mathrm{Mn}$ \\
\hline Wastewater1 & 0.2501 & 0.3217 & 2.6 & 5.7 & 0.2498 & 0.3316 \\
Wastewater2 & 0.5384 & 0.7528 & 3.1 & 4.9 & 0.5299 & 0.7481 \\
\hline
\end{tabular}

\section{Conclusion}

A new method to determine $\mathrm{Cr}(\mathrm{VI})$ and $\mathrm{Mn}(\mathrm{VII})$ by differential reaction rate kinetic direct yellow brown D3G fading spectrophotometry was purposed. The Beer's law was obeyed in $0-11 \mu \mathrm{g} / \mathrm{mL}$ and $0-9.8 \mu \mathrm{g} / \mathrm{mL}$ for $\mathrm{Cr}(\mathrm{VI})$ and $\mathrm{Mn}(\mathrm{VII})$. The detection limits of $\mathrm{Cr}(\mathrm{VI})$ and $\mathrm{Mn}(\mathrm{VII})$ were $0.81 \mu \mathrm{g} / \mathrm{mL}$ and $0.11 \mu \mathrm{g} / \mathrm{mL}$, respectively. This method could be used to determine $\mathrm{Cr}(\mathrm{VI})$ and $\mathrm{Mn}(\mathrm{VII})$ in industrial wastewater with satisfactory results.

\section{REFERENCES}

1. State Environmental Protection Administration of China. Analysis Method of Water and Waste Water, China Environmental Science Press, Inc. Beijing, end. 4, pp. 344-372 (2002).

2. P. Olmedo, A. Pla, A.F. Hernández, O. López-Guarnido, L. Rodrigo and F. Gil, Anal. Chim. Acta, 659, 60 (2010).

3. A.N. Anthemidis and S.-J.V. Koussoroplis, Talanta, 71, 1728 (2007).

4. M. Tùrkmen and C. Ciminli, Food Chem., 103, 670 (2007).

5. D. Zhang, H.D. Su and P. Yu, Phys. Test. Chem. Anal.-Part B: Chem. Anal., 43, 325 (2007).

6. D. Zhang, P. Yu and J.J. Gao, Plat. Finish., 28, 47 2006).

7. J.H. Yu, Q.Y. Ou and Y.Y. Mu, Chin. J. Anal. Chem., 31, 587 (2003).

8. D. Zhang, P. Yu and J.J. Gao, Metal. Anal., 25, 10 (2005).

9. D. Zhang, S.H. Ba and J.J. Gao, Metal. Anal., 26, 44 (2006).

10. D. Zhang, C.L. Zhang and L. Wan, Metal. Anal., 28, 39 (2006). 